\title{
The contribution of phytoplankton in the carbon adsorption and stock during shrimp culture in brackishwater ponds
}

\author{
BAMBANG WIDIGDO ${ }^{1, \vartheta}$, MUHAMMAD RIFQI ${ }^{2,3}$, ALI MASHAR ${ }^{1}$, FITRINA NAZAR $^{4}$, YUSLI WARDIATNO $^{1,5,6}$ \\ ${ }^{1}$ Department of Aquatic Resources Management, Institut Pertanian Bogor. J1. Lingkar Akademik, Kampus IPB Dramaga, Bogor 16680, West Java, \\ Indonesia. Tel.: +62-51-8624360, Fax.: +62-51-8622932, ^email: bbg_widigdo@yahoo.co.id \\ ${ }^{2}$ Doctoral Program in Coastal and Marine Resources Management, Graduated School, Institut Pertanian Bogor. Jl. Raya Darmaga, Bogor 16680, West \\ Java, Indonesia \\ ${ }^{3}$ Directorate General of Aquaculture, Ministry of Marine Affairs and Fisheries. J1. Medan Merdeka Timur No. 16, Gedung Mina Bahari IV, Lt. 5,6,7,8 \\ Jakarta Pusat 10110, Jakarta, Indonesia \\ ${ }^{4}$ Politeknik Ahli Usaha Perikanan Jakarta. Jl. Raya Pasar Minggu, Jakarta Selatan 12520, Jakarta, Indonesia \\ ${ }^{5}$ Environmental Research Center, Institut Pertanian Bogor. Jl. Raya Darmaga, Bogor 16680, West Java, Indonesia \\ ${ }^{6}$ Center for Coastal and Marine Resources Studies, Institut Pertanian Bogor. Jl. Raya Pajajaran, Kampus IPB Baranangsiang, Bogor 16143, West Java, \\ Indonesia
}

Manuscript received: 20 August 2020. Revision accepted: 14 October 2020.

\begin{abstract}
Widigdo B, Rifqi M, Mashar A, Nazar F, Wardiatno Y. 2020. The contribution of phytoplankton in the carbon adsorption and stock during shrimp culture in brackishwater ponds. Biodiversitas 21: 5170-5177. In environmental point of view, it is important to determine the potential of adsorption and stock of blue carbon during shrimp farming in ponds with three cultivation technologies namely: extensive/traditional, semi-intensive, and intensive. The aquatic primary productivity approach is used to measure the potential of carbon adsorption in shrimp ponds, while the carbon conversion of chlorophyll-a content is used to measure its stock. The primary productivity and chlorophyll-a content were measured using three ponds for each cultivation technology every ten days from stocking (DOC 0 ) until the harvest period. The sampling location is in the BLUPPB shrimp pond area of Karawang, West Java - Indonesia. The study concluded that the adsorption and stock of blue carbon varied during shrimp farming in ponds. The primary productivity and chlorophyll-a content of the three cultivation technologies were the significant difference as the results of ANOVA Single Factor. Carbon adsorption average during extensive/traditional, semi-intensive, and intensive shrimp farming in ponds was $1.912832 \mathrm{~g} \mathrm{C} \mathrm{m}^{-3}$ day $^{-1}, 7.097145 \mathrm{~g} \mathrm{C} \mathrm{m}^{-3}$ day $^{-1}$ and $8.250195 \mathrm{~g} \mathrm{C} \mathrm{m}^{-3}$ day $^{-1}$, respectively. While, the average carbon stock during shrimp farming in extensive/traditional, semi-intensive, and intensive ponds were $0.64896 \mathrm{~g} \mathrm{~m}^{-3}, 14.97473 \mathrm{~g} \mathrm{~m}^{-3}$, and $25.11102 \mathrm{~g} \mathrm{~m}^{-3}$, respectively.
\end{abstract}

Keywords: Carbon chlorophyll-a ratio, carbon sink, primary productivity

\section{INTRODUCTION}

The Indonesian mangroves that convert into shrimp ponds have happened since the 1800s (Ilman et al. 2016), which caused blue carbon emission. The emission is due to the loss of approximately $79.2-242.2$ tons $\mathrm{C} \mathrm{ha}^{-1}$ carbon stocks (Hilmi et al. 2017), carbon burial deficiency of 1.15 - 2.70 tons ha $^{-1}$ year $^{-1}$ (Bianchi et al. 2013; Siikamäki et al. 2013), loss of $\mathrm{CO}_{2}$ sequestration capacity from 36.52 263.85 tons ha $^{-1}$ year $^{-1}$ (Chen et al. 2016; Rahman et al. 2017) and the release of $262-1,084$ tons ha $^{-1}$ carbon stored in the substrate of the mangrove (Siikamäki et al. 2013; Kauffman et al. 2014; Liu et al. 2014). The conversion of mangroves into shrimp ponds resulted in the loss of $58 \%$ $82 \%$ carbon stock in its ecosystems with an average potential emission of $1,390 \mathrm{Mg} \mathrm{CO}_{2}-\mathrm{e} \mathrm{ha}^{-1}$ (Kauffman et al. 2018).

The potential emission of $\mathrm{CO}_{2}$ during shrimp farming was $0.02436 \mathrm{~g} \mathrm{C} \mathrm{m}^{-2} \mathrm{day}^{-1}$ or 0.08037 ton $\mathrm{C} \mathrm{ha}^{-1}$ year $^{-1}$ from the surface of the pond water (Rifqi et al. 2020), 4.37 $\mathrm{kg} \mathrm{CO}_{2}$ per $\mathrm{m}^{2}$ year ${ }^{-1}$ from embankments, and $1.60 \mathrm{~kg} \mathrm{CO}_{2}$ per $\mathrm{m}^{2}$ year-1 from the substruction of intensive shrimp ponds (Sidik and Lovelock, 2013). Furthermore, $89.48 \mathrm{~kg}$ $\mathrm{CO}_{2}$ day $^{-1}$ - $751.87 \mathrm{~kg} \mathrm{CO}_{2}$ day $^{-1}$ fossil fuels were derived, and the potential emission of $\mathrm{CH}_{4}$ was from 0.45 - 64.61 $\mathrm{mg} \mathrm{kg}{ }^{-1}$ waste year ${ }^{-1}$ during the shrimp culture period (Dewata 2013).

Nevertheless, shrimp farming adsorbs $\mathrm{CO}_{2}$ through the photosynthetic activities of phytoplankton and production of the carbon as aquatic organism biomass. Microalgae adsorbs $\mathrm{CO}_{2}$ and stores carbon in form of biomass (Bhakta et al. 2015). The presence of phytoplankton in aquaculture production systems contribute to carbon cycle and aquatic food chain (Wetzel 2001; Lee et al. 2014; Ma et al. 2014; Xiao et al. 2015; Mercado-santana et al. 2017), because of their photosynthetic activities (Mitra and Zaman 2015) and assimilates or adsorbs $\mathrm{CO}_{2}$ (Geider and Osborne 1992; Baker 2004). Furthermore, in aquatic ecosystems, phytoplankton or microalgae are the major contributors to primary productivity (Nontji 1984; Iriarte and Purdie 1994; Chen et al. 2017; Reeder 2017; Vallina et al. 2017) while the rest are plants and macroalgae (Silva et al. 2009). The determination of primary productivity is an approach used to calculate carbon adsorption. Blue carbon stock is stored in form of phytoplankton and aquatic animal biomasses in the coastal aquatic ecosystem (Mitra and Zaman 2015).

However, some experts question the existence of phytoplankton biomass as one of the blue carbon stocks, 
because of its relatively short life span and inability to form their own organic-rich sediments. Phytoplankton biomass is a rich carbon source and it significantly contributes to the detritus habitat, therefore it tends to act as a carbon donor (Hill et al. 2015). Microalgae as a $\mathrm{CO}_{2}$ biology adsorbent is reported by Singh and Ahluwalia (2013) as a promising technology because of its superiority over other aquatic plants. Reduction of blue carbon emissions as one of the greenhouse gases tends to ultimately support the sustainability of aquaculture businesses (Ahmed et al 2017). This study to determine blue carbon adsorption and stock during shrimp culture in the ponds.

\section{MATERIALS AND METHODS}

\section{Study area}

The research was carried out in nine shrimp ponds located at the BLUPPB Karawang, West Java, Indonesia on April - July 2019. Among those nine ponds, three of them are located in Block F4 sizing of $5,000 \mathrm{~m}^{2}$ and of earthen. The second three ponds located in Block $\mathrm{J} 2$ having size of $2,000 \mathrm{~m}^{2}$ and covered with high-density polyethylene (HDPE), while the last three ponds located in Block F3 having size of $2,400 \mathrm{~m}^{2}$ and covered with mulch plastic. The first three ponds (Block F4) were used as an extensive/traditional shrimp culture, the second (Block J2) and the third (Block F3) were used as semi-intensive and intensive shrimp culture, respectively. All ponds received water supplied from the same irrigation unit. Coastal water which was mixed with groundwater to meet proper salinity supplied to the ponds.

The SPF shrimp post larvae stocked to all ponds supplied of locals hatchery at density of $5 \mathrm{PL} \mathrm{m}^{-2}, 70 \mathrm{PL} \mathrm{m}$ 2, and $145 \mathrm{PL} \mathrm{m}^{-2}$ for extensive/traditional, semi-intensive and intensive shrimp culture, respectively. The protocol of shrimp culture followed Standard Operation Procedure (SOP) as determined by the technician. The shrimp cultured in extensive way received their feed from natural sources. While the shrimp in the semi-intensive and intensive ponds were fed 4-5 times a day. Weekly growth and ages used to predict the feeding rate. No paddlewheel aerator supports extensive/traditional ponds. While in the semi-intensive ponds was equipped with three units electrical paddlewheel aerator and intensive pond was equipped with eight units of electrical paddlewheel aerator. The new water was added to the shrimp ponds during the first 30 days of culture in the semi-intensive and intensive to replace water that lost by evapotranspiration, onward every 3-5 days of 3-5\% water exchange to keep water on proper quality. At the water exchange, the bottom mud is removed to reduce the organic matter in the pond. Conversely, no water exchange in extensive/traditional pond. The new water is added only carried out to replace volume loss.

\section{Primary productivity (PP) and carbon adsorption}

Measurement of primary productivity was carried out every ten days in the three ponds for each shrimp culture technology. The oxygen method was widely used to determine primary productivity (Yang et al. 2002). It was measured by referring to the APA standard method part 10000 at $10200 \mathrm{~J}$ (APA 2012), which is similar to the oxygen method using dark and light bottles (Wetzel 2001; Alianto et al. 2008). Oxygen content in the sample bottles was measured using DO meters (Krismono et al. 2017; Mardhiya et al. 2017). The primary productivity was calculated using the Umaly and Cuvin (1988) formula:

$$
\mathrm{PP}\left(\mathrm{mg} \mathrm{C} \mathrm{m}^{-3} \text { hours }^{-1}\right)=\frac{\left(0_{2} L B\right)-\left(O_{2} D B\right)(1,000)}{(P Q)(t)} \times 0.375
$$

Where: $\mathrm{O}_{2}=$ dissolved oxygen $\left(\mathrm{mg} \mathrm{l}^{-1}\right) ; \mathrm{LB}=$ light bottle; $\mathrm{DB}=$ dark bottle; $\mathrm{PQ}=$ photosynthetic quotient (1.2); $\mathrm{t}=$ incubation duration (hours) $; 1.000=$ conversion of liters to $\mathrm{m}^{3} ; 0.375=$ the conversion coefficient of oxygen to carbon $(12 / 32)$.

The adsorption of carbon in shrimp ponds is suspected to determine primary productivity. According to Singh and Ahluwalia (2013), it is the production of atmospheric and aquatic $\mathrm{CO}_{2}$ by organic macromolecules, particularly during photosynthesis. The number of oxygen molecules produced was not the same as the assimilated carbon dioxide. Furthermore, photosynthetic quotient (PQ) is expressed as the rate of oxygen evolution to the amount of carbon dioxide assimilated during photosynthesis (Geider and Osborne 1992).

\section{Chlorophyll-a content and carbon stock}

Water sampling for the determination of chlorophyll-a content was carried out every ten days in the three ponds for each shrimp culture technology. Conversely, phytoplankton biomass is stated in relation to the chlorophyll-a pigment content (Kaswadji et al. 1993). The pigment content was calculated using the spectrophotometer technique (Parsons et al. 1992) which is referred to as the APA standard method part 10000 at $10200 \mathrm{H}$. The amount of chlorophyll is calculated using the APA (2012) equation:

$C a\left(\frac{m g}{m^{3}}\right)=\frac{11 \times 2.43 \times\left[\left(A 664_{b}-A 750_{b}\right)-\left(A 665_{a}-A 750_{a}\right)\right] \times V_{1}}{V_{2} \times L}$

Where: $\mathrm{Ca}=$ the amount of chlorophyll- $a\left(\mathrm{mg} \mathrm{m}^{-3}\right) ; \mathrm{V}_{1}$ = extract volume $(\mathrm{mL}) ; \mathrm{V}_{2}=$ sample volume $\left.\mathrm{L}\right) ; \mathrm{L}=$ cuvette length or width $(\mathrm{cm}) ; \mathrm{A} 750_{\mathrm{b}}=$ absorbance at 750 $\eta \mathrm{m}$ wavelength before acidification; $\mathrm{A} 750_{\mathrm{a}}=$ absorbance at $750 \mathrm{\eta m}$ wavelength after acidification; $\mathrm{A} 664_{\mathrm{b}}=$ absorbance at $664 \eta \mathrm{m}$ wavelength before acidification; A665 $=$ absorbance at $665 \eta \mathrm{m}$ wavelength after acidification.

The chlorophyll content in phytoplankton and other biomass parameters were determined using a conversion approach (Nontji 1984). The conversion factor used in this study was 1: 75 (Gieskes and Kraay 1989).

\section{Statistical analysis}

The difference in primary productivity and chlorophylla content of the three cultivation technologies was determined by ANOVA single factor (Yang et al. 2017) and Tukey's HSD (honestly significant difference) for post 
hoc test. The estimated average value of carbon adsorption and stock in the shrimp ponds was calculated using the single exponential smoothing (SES) method. SES is a method of modifying data by removing the irregular components in it (Risteski et al. 2004; Gardner and DiazSaiz 2008; Raharja et al. 2010). The difficult aspect of this method is in discovering the ideal parameter/value used to obtain the least possible error. Package forecasts in $\mathrm{R}$ software is used to identify the perfect parameter/values in historical data (Chapman and Feit 2019).

\section{RESULTS AND DISCUSSION}

\section{Primary productivity and carbon adsorption}

Dynamic of primary productivity (PP) during shrimp farming in the three ponds are shown in Figure 1, with a general increase in PP from the stocking start (DOC 0) to harvest period.

The primary productivity in the intensive shrimp ponds at the beginning of cultivation (DOC 0) was $204.86 \mathrm{mg} \mathrm{C}$ $\mathrm{m}^{-3}$ hours $^{-1}$ which later increased to $780.38 \mathrm{mg} \mathrm{C} \mathrm{m}^{-3}$ hours
${ }^{1}$ during the harvest period (DOC 70). On the contrary, the $\mathrm{PP}$ in the semi-intensive shrimp ponds at the beginning of cultivation (DOC 0) was $75.61 \mathrm{mg} \mathrm{C} \mathrm{m}^{-3}$ hours $^{-1}$ which further increased to $594.27 \mathrm{mg} \mathrm{C} \mathrm{m}^{-3}$ hours $^{-1}$ during the harvest period (DOC 110). Lower PP values ranging from $35.19 \mathrm{mg} \mathrm{C} \mathrm{m}^{-3}$ hours $^{-1}$ to $209.03 \mathrm{mg} \mathrm{C} \mathrm{m}^{-3}$ hours $^{-1}$ was discovered in the extensive/traditional shrimp ponds.

The primary productivity of the three cultivation technologies was a significant difference as the results of ANOVA Single Factor ( $p$-value $0.000112<\alpha 0.01$ ). Inverse transformation was carried out to ascertain that the data is distributed normally. Kolmogorov Smirnov Test was used to conduct the data normality test. The post hoc results obtained by using Tukey's HSD test shows the actual difference between extensive/traditional and semiintensive technology, and that between extensive/traditional and intensive technology. However, there was no significant difference between semi-intensive and intensive technology.

The carbon adsorption day $^{-1}$ from three cultivation technologies is presented in Figure 2.

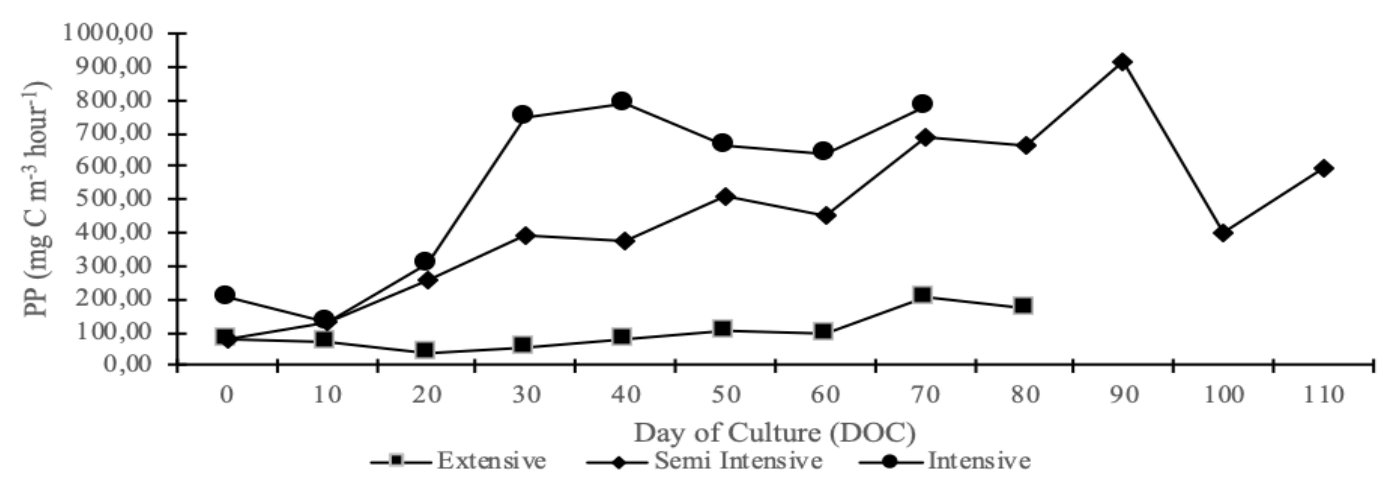

Figure 1. Primary productivity during shrimp farming in ponds with three different culture technologies in Karawang, West Java, Indonesia

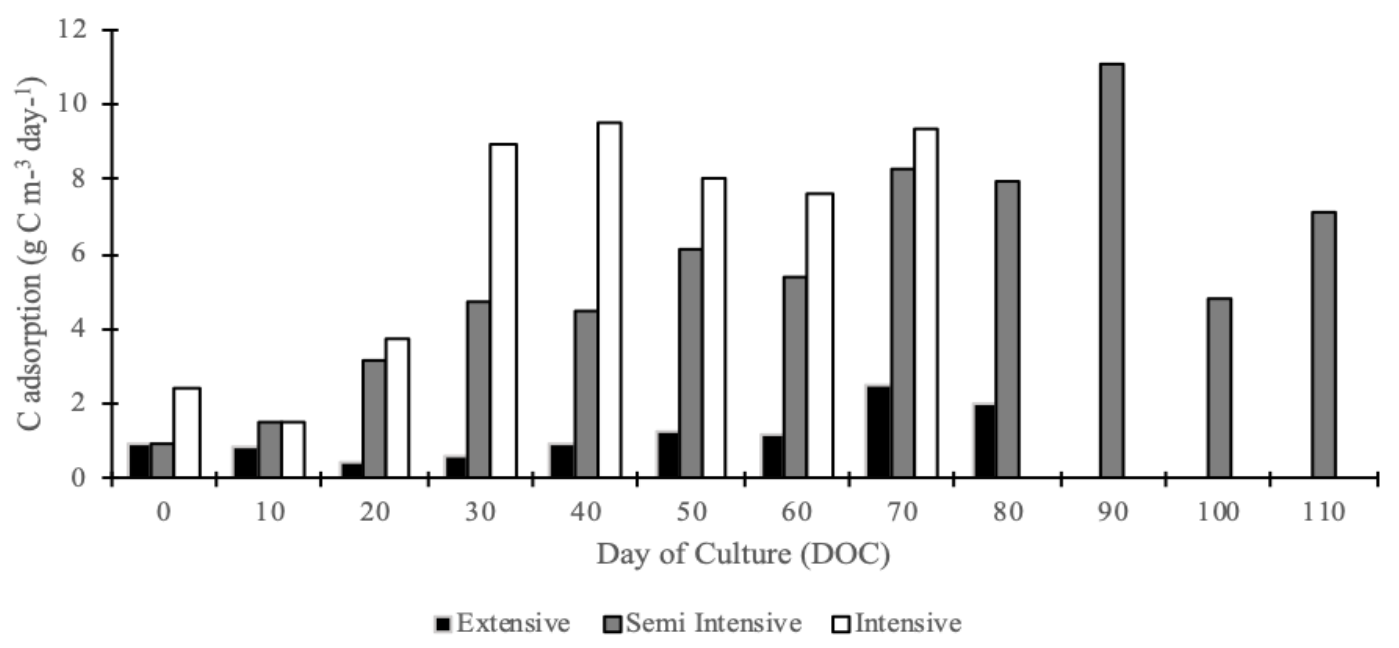

Figure 2. Daily carbon adsorption during shrimp farming in ponds with three different culture technologies in Karawang, West Java, Indonesia 
Figure 2 shows the various changes in carbon adsorption in the ponds. There was an increase from the beginning of stocking (DOC 0 ) to the end of cultivation (harvest) in the three shrimp cultivation technologies. The highest average of carbon adsorption was detected in the intensive ponds with a value of $2.46 \mathrm{~g} \mathrm{C} \mathrm{m}^{-3}$ day $^{-1}$ obtained at stocking (DOC 0) which increased to $9.37 \mathrm{~g} \mathrm{C} \mathrm{m}^{-3}$ day $^{-1}$ at the harvest period (DOC 70). In the semi-intensive ponds was obtained $0.91 \mathrm{~g} \mathrm{C} \mathrm{m}^{-3} \mathrm{day}^{-1}$ at the beginning of the cultivation (DOC 0) and increased to $7.13 \mathrm{~g} \mathrm{C} \mathrm{m}^{-3} \mathrm{day}^{-1}$ at the harvest period (DOC 110). And in the extensive/traditional pond ranging from $0.42 \mathrm{~g} \mathrm{C} \mathrm{m}^{-3}$ day $^{-1}$ (DOC 0) and it later increased to $2.51 \mathrm{~g} \mathrm{C} \mathrm{m}^{-3} \mathrm{day}^{-1}$ at the harvest period (DOC 80).

Carbon adsorption during shrimp farming in the ponds was determined daily by estimating its average using simple exponential smoothing (SES) as shown in Table 1 and Figure 3. The results from the SES analysis, shows that the average carbon adsorption in intensive, semi-intensive, and extensive/traditional ponds were $8.250195 \mathrm{~g} \mathrm{C} \mathrm{m}^{-3}$ day $^{-1}, 7.097145 \mathrm{~g} \mathrm{C} \mathrm{m}^{-3}$ day $^{-1}$ and $1.912832 \mathrm{~g} \mathrm{C} \mathrm{m}^{-3}$ day $^{-1}$, respectively.

\section{Chlorophyll-a and carbon stock}

Variation of chlorophyll-a content in the three cultivation technologies is shown in Figure 4. Relatively large changes are detected in semi-intensive and intensive ponds from stocking (DOC 0) to harvest period. The chlorophyll- $a$ content of intensive and semi-intensive cultivation technology is higher than the extensive/traditional ponds. The contents of the intensive shrimp ponds at the beginning of cultivation (DOC 0 ) was $153.97 \mathrm{mg} \mathrm{m}^{-3}$, which increased to $356.89 \mathrm{mg} \mathrm{m}^{-3}$ during the harvest period (DOC 70). The contents in the semiintensive shrimp ponds at the beginning of cultivation (DOC 0) were $7.83 \mathrm{mg} \mathrm{m}^{-3}$ however, it later increased to $143.74 \mathrm{mg} \mathrm{m}^{-3}$ at the harvest period (DOC 110). The chlorophyll-a content in extensive/traditional shrimp ponds was low, ranging from $2.14 \mathrm{mg}^{-3}$ to $8.0 \mathrm{mg} \mathrm{m}^{-3}$.

There was a significant difference between the chlorophyll-a content of the three cultivation technologies (extensive/traditional, semi-intensive, and intensive) as the results of the single factor ANOVA test (p-value $0.0000000<\alpha$ 0.01). Logarithmic transformation was carried out in order to ensure the data is distributed normally. Data normality test was conducted by using the Kolmogorov Smirnov. The post hoc results obtained using Tukey's HSD test shows that a significant change occurred in the three cultivation technologies. Figure 5 shows the carbon stock in the three different technology of shrimp ponds.

Figure 5 shows the changes increased steadily from the beginning of stocking to the end of cultivation (harvest), except for extensive/traditional ponds. Carbon stock in the semi-intensive pond was 5.87 tons $\mathrm{C} \mathrm{ha}^{-1}$ at the beginning of cultivation (DOC 0) which was later increased to 107.80 tons $\mathrm{C} \mathrm{ha} \mathrm{h}^{-1} 1$ at the harvest period (DOC 110). Average carbon content of 115.48 tons $\mathrm{C} \mathrm{ha}^{-1}$ at stocking (DOC 0) was found in intensive ponds and this increase to 267.67 tons $\mathrm{C} \mathrm{ha}^{-1}$ at the harvest period (DOC 70). Conversely, carbon stock in extensive/traditional ponds was 8.28 tons $\mathrm{C}$ $\mathrm{ha}^{-1}$ at the beginning of cultivation and later decrease to 7.51 tons $\mathrm{C} \mathrm{ha}^{-1}$ at the harvest period (DOC 80).

Estimated average of carbon stock in the shrimp pond was determined using simple exponential smoothing (SES) as shown in Table 2 and Figure 6.

Table 1. The estimated average of carbon adsorption in the shrimp pond using single exponential smoothing method

\begin{tabular}{|c|c|c|c|c|c|}
\hline \multirow{2}{*}{ Cultivation technology } & \multirow{2}{*}{$\begin{array}{l}\text { Estimated average } \\
\qquad\left(\mathrm{g} \mathrm{C} \mathrm{m}^{-3} \text { day }^{-1}\right)\end{array}$} & \multicolumn{2}{|c|}{$80 \%$ confidence rate } & \multicolumn{2}{|c|}{$95 \%$ confidence rate } \\
\hline & & Lo & Hi & Lo & Hi \\
\hline Extensive/Traditional & 1.912832 & 1.123965 & 2.701699 & 0.7063636 & 3.1193 \\
\hline Semi-intensive & 7.097145 & 3.891806 & 10.30248 & 2.195002 & 11.99929 \\
\hline Intensive & 8.250195 & 4.112752 & 12.38764 & 1.922522 & 14.57787 \\
\hline
\end{tabular}

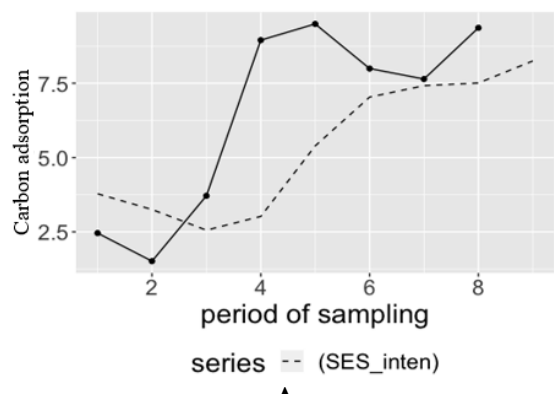

A
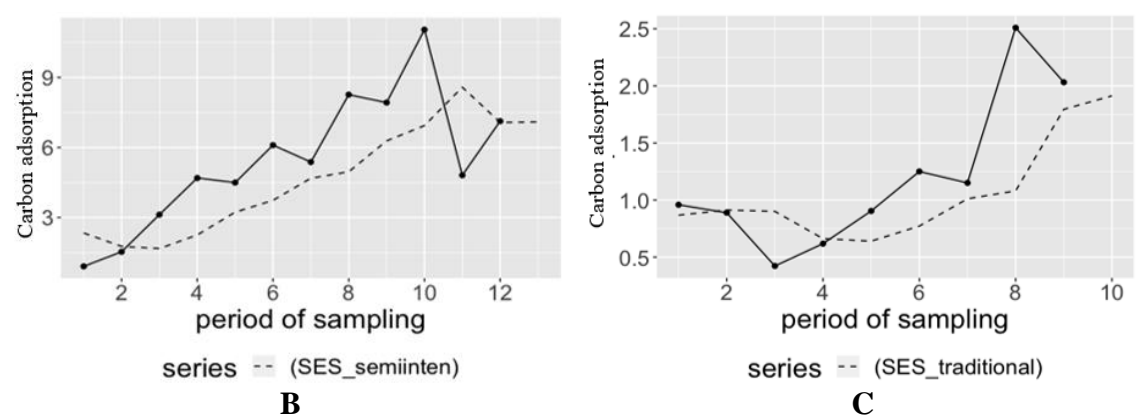

C

Figure 3. Graph of estimating a model of carbon adsorption in the cultivation technology of (A) intensive, (B) semi-intensive, and extensive/traditional shrimp ponds 


\section{Total carbon adsorption and stock during shrimp} culture

Based on the estimated average value, the total carbon absorption and stock determined during shrimp farming in extensive/traditional, semi-intensive, and intensive ponds, are shown in Table 3. According to the results from the SES analysis, the daily estimated average of carbon stock in intensive, semi-intensive, and extensive/traditional shrimp ponds was $25.11102 \mathrm{~g} \mathrm{~m}^{-3}, 14.97473 \mathrm{~g} \mathrm{~m}^{-3}$, and $0.64896 \mathrm{~g} \mathrm{~m}^{-3}$, respectively.

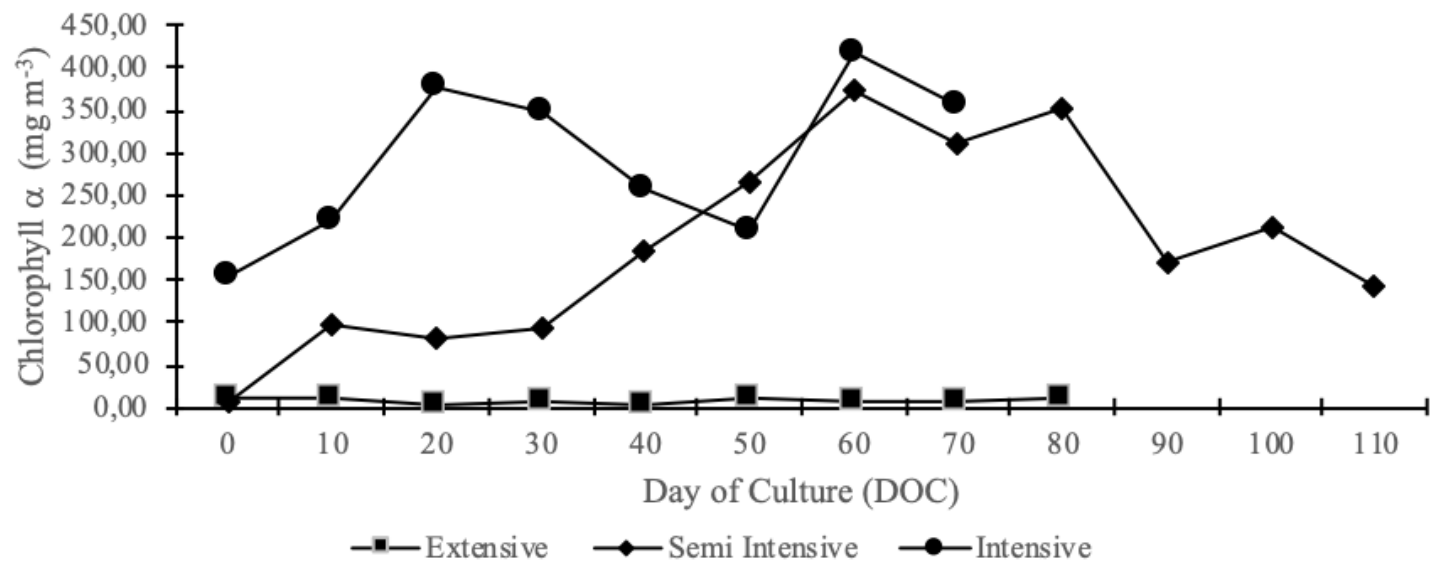

Figure 4. Chlorophyll-a content during shrimp farming in ponds with three different culture technologies in Karawang, West Java, Indonesia

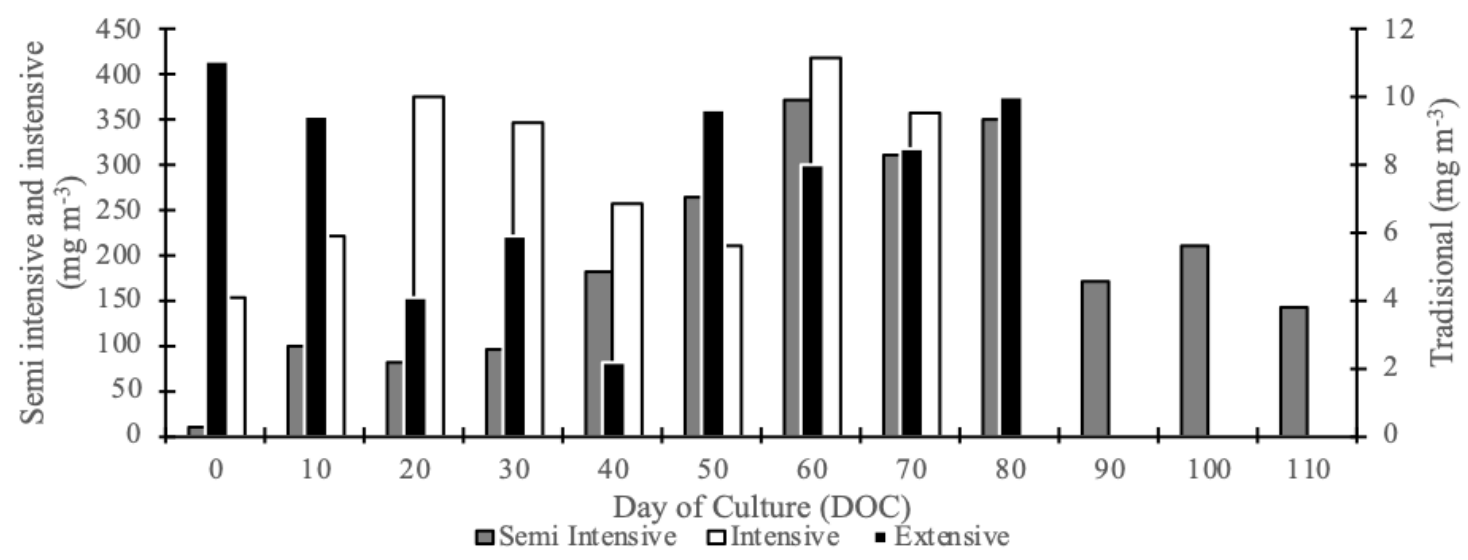

Figure 5. Carbon stock during shrimp farming in ponds with three different culture technologies in Karawang, West Java, Indonesia

Table 2. The estimated average carbon stock in the shrimp pond using single exponential smoothing method

\begin{tabular}{lccccc}
\hline \multirow{2}{*}{ Cultivation technology } & Estimated average & \multicolumn{2}{c}{$\mathbf{8 0 \%}$ confidence rate } & \multicolumn{2}{c}{$\mathbf{9 5 \%}$ confidence rate } \\
\cline { 5 - 6 }$\left(\mathbf{g ~ m}^{-\mathbf{3}}\right)$ & Lo & Hi & \multicolumn{2}{c}{ Lo } & Hi \\
\hline Extensive/ traditional & & & & & \\
Semi-intensive & 0.64896 & 0.306193 & 0.991727 & 0.12474 & 1.17318 \\
Intensive & 14.97473 & 4.760039 & 25.18942 & -0.64729 & 30.59676 \\
& 25.11102 & 14.34295 & 35.87908 & 8.64268 & 41.57935 \\
\hline
\end{tabular}



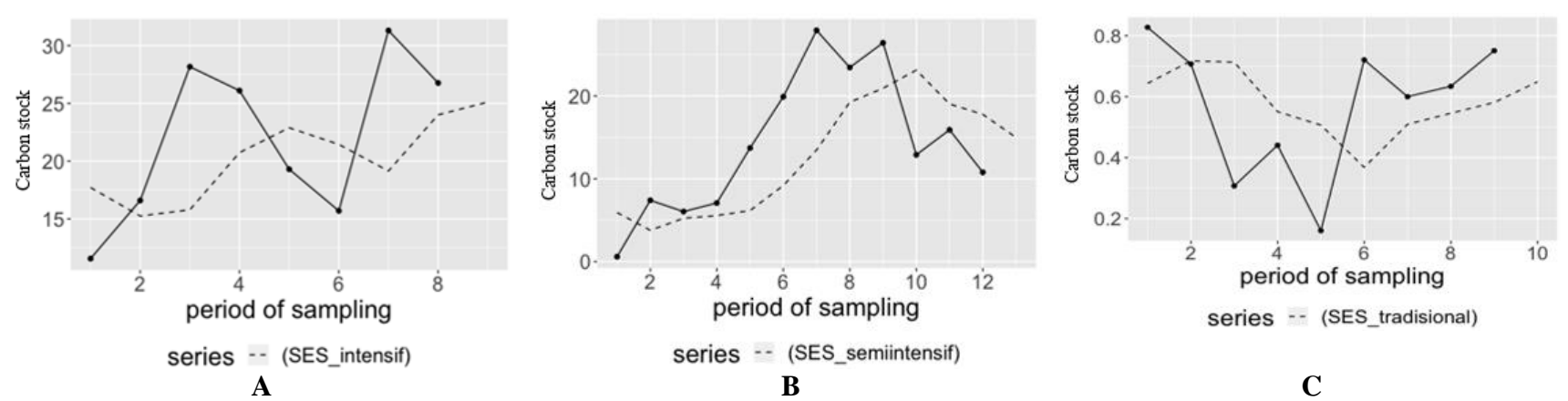

Figure 6. Graph of estimating a model of carbon stock in shrimp cultivation technology at (A) intensive (B) semi-intensive and (C) extensive/traditional shrimp ponds

Table 3. The total carbon adsorption and stock during shrimp farming in ponds

\begin{tabular}{|c|c|c|c|c|}
\hline Cultivation technology & Estimated average & $\begin{array}{c}\text { Pond volume } \\
\left(\mathbf{m}^{3}\right)\end{array}$ & $\begin{array}{c}\text { Duration of culture } \\
\text { (days) }\end{array}$ & Total \\
\hline Extensive/ traditional & $\begin{array}{l}\mathrm{Ad}=1.91283 \mathrm{~g} \mathrm{C} \mathrm{m}^{-3} \mathrm{day}^{-1} \\
\mathrm{Sc}=0.64896 \mathrm{~g} \mathrm{~m}^{-3}\end{array}$ & 10.000 & 110 & $\begin{array}{l}\mathrm{Ad}=0.7139 \text { ton } \mathrm{C} \\
\mathrm{Sc}=0.0071 \text { ton }\end{array}$ \\
\hline Semi intensive & $\begin{array}{l}\mathrm{Ad}=7.09715 \mathrm{~g} \mathrm{C} \mathrm{m}^{-3} \mathrm{day}^{-1} \\
\mathrm{Sc}=14.97473 \mathrm{~g} \mathrm{~m}^{-3}\end{array}$ & 10.000 & 110 & $\begin{array}{l}\mathrm{Ad}=7.8069 \text { ton } \mathrm{C} \\
\mathrm{Sc}=0.1560 \text { ton }\end{array}$ \\
\hline Intensive & $\begin{array}{l}\mathrm{Ad}=8.25020 \mathrm{~g} \mathrm{C} \mathrm{m}^{-3} \mathrm{day}^{-1} \\
\mathrm{Sc}=25.11102 \mathrm{~g} \mathrm{~m}^{-3}\end{array}$ & 10.000 & 110 & $\begin{array}{l}\mathrm{Ad}=9.0752 \text { ton } \mathrm{C} \\
\mathrm{Sc}=0.2663 \text { ton }\end{array}$ \\
\hline
\end{tabular}

Note: Ad: Carbon adsorption; Sc: Carbon stock

\section{Discussion}

The environmental factors that influence the absorption of $\mathrm{CO}_{2}$ are light intensity, temperature, and the concentration of $\mathrm{CO}_{2}$ and $\mathrm{pH}$ (Bhakta et al. 2015). According to Moreira and Pires (2016), $\mathrm{CO}_{2}$ adsorption occurs through two processes, such as pump solubility and biological sequestration. Microalgae is a productive biological system that produces biomass and absorbs carbon (Sayre 2010). It is effective for capturing and adsorbing atmospheric $\mathrm{CO}_{2}$ (Sayre 2010; Moreira and Pires 2016). The existence of algae in the aquatic ecosystem serves as a controller of $\mathrm{CO}_{2}$ released into the air, because it rapidly converts $\mathrm{CO}_{2}$ into organic material through photosynthesis unlike terrestrial plants (Jeong et al. 2003). The efficiency of microalgae to convert $\mathrm{CO}_{2}$ during photosynthesis ranges from $10-29 \%$ while terrestrial plants are from 1-2\%, however, some types of microalgae are able to increase their biomass within 3.5 hours (Chisti 2007). The fastest-growing microalgae are Chlorella pyrenoidosa with 1.17 optical density per five days (Jeong et al. 2003). It is a phototrophic microorganism with simple nutritional requirements and also acts as a primary producer (Singh and Ahluwalia 2013).

Several methods are used to determine phytoplankton biomass, such as cell counting, cell volume measurement, ATP, DNA, and chlorophyll a content (Nontji 1984; Steigenberger et al. 2004). All photosynthetic cells contain one or several chlorophyll pigments, such as green, brown, red, or violet (Wetzel 2001; Kirk 2011). Chlorophyll a concentration is the main indicator used to estimate primary productivity and an important variable in photosynthetic process (Lee et al. 2014; Xiao et al. 2015; Chen et al. 2017). Algae have an efficient photosynthetic mechanism and high biomass production (Moreira and Pires 2016). Microalgae develop rapidly with high biomass productivity. Microalga is a bio-mitigating organism (Moreira and Pires 2016). Numerous studies including Gieskes and Kraay (1989) stated that the ratio of carbon to chlorophyll is 1:75 and 1: 125 in the different parts of the Banda Sea, Indonesia.

The high carbon content of phytoplankton in the aquatic ecosystem compared to primary productivity indicates the level of $\mathrm{CO}_{2}$ adsorption and the water volume unit at a certain time (Gieskes and Kraay 1989). The high carbon content in intensive and semi-intensive ponds is possible due to the availability of sufficient nutrients that support the growth of phytoplankton, this is in accordance with the research conducted by de Jonge (1980).

The adsorption of carbon during shrimp farming in extensive/traditional, semi-intensive, and intensive ponds was 0.7139 tons $\mathrm{C} \mathrm{ha}^{-1}, 7,8069$ tons $\mathrm{Cha}^{-1}$, and 9,0752 tons $\mathrm{C} \mathrm{ha}^{-1}$, respectively. That ability of carbon adsorption is lower than the mangrove ecosystem, it was $36.52-263.85$ tons $\mathrm{C} \mathrm{ha}^{-1}$ (Chen et al. 2016; Rahman et al. 2017). Carbon stock in the extensive/traditional, semi-intensive, and intensive ponds was 0.0071 tons $\mathrm{ha}^{-1}, 0.1560$ tons $\mathrm{ha}^{-1}$, and 0.2663 tons $\mathrm{ha}^{-1}$, respectively. That carbon stock is still much lower than the mangrove ecosystem carbon stock, it was 79.2 - 242.2 tons ha ${ }^{-1}$ (Hilmi et al. 2017). 


\section{ACKNOWLEDGEMENTS}

This research was funded by the Marine and Fisheries Education Center Scholarship of Ministry of Marine Affairs and Fisheries, Indonesia. The author is grateful to the Brackish Aquaculture Division Team and the BLUPPB Karawang (Aquaculture Production Business Service Center) Test Laboratory Team for their assistance and support.

\section{REFERENCES}

Ahmed N, Cheung WWL, Thompson S, Glaser M. 2017. Solutions to blue carbon emissions: Shrimp cultivation, mangrove deforestation, and climate change in coastal Bangladesh. Mar Policy 82: 68-75. DOI: 10.1016/j.marpol.2017.05.007.

Alianto, Adiwilaga EM, Damar A. 2008. Primary productivity of phytoplankton and its association with nutrients and light in the waters of Banten Bay. Jurnal Ilmu-ilmu Perairan dan Perikanan Indonesia 15 (1): 21-26. [Indonesian]

APHA [American Public Health Association]. 2012. Standard methode for the examination of water and wastewater 22nd ed., American Public Health Association, USA.

Baker NR. 2004. Photosynthesis and the Environment. Kluwer Academic Publisher, New York.

Bhakta JN, Lahiri S, Pittman JK, Jana BB. 2015. Carbon dioxide sequestration in wastewater by a consortium of elevated carbon dioxide-tolerant microalgae. $\mathrm{J} \quad \mathrm{CO}_{2}$ Util 10: 105-112. DOI: 10.1016/j.jcou.2015.02.001.

Bianchi TS, Allison MA, Zhao J, Li X, Comeaux RS, Feagin RA, Kulawardhana RW. 2013. Historical reconstruction of mangrove expansion in the Gulf of Mexico: Linking climate change with carbon sequestration in coastal wetlands. Estuar Coast Shelf Sci 119: 7-16. DOI: $10.1016 /$ j.ecss.2012.12.007.

Chapman C, Feit EM. 2019. R for Marketing Research and Analytics. $2^{\text {nd }}$ ed. Springer Nature, Cham, Switzerland.

Chen G, Chen B, Yu D, Tam NFY, Ye Y, Chen S. 2016. Soil greenhouse gas emissions reduce the contribution of mangrove plants to the atmospheric cooling effect. Environ Res Lett 11: 1-10. DOI: 10.1088/1748-9326/11/12/124019.

Chen H, Zhou W, Chen W, Xie W, Jiang L, Liang Q, Huang M, Wu Z, Wang Q. 2017. Simplified, rapid, and inexpensive estimation of wate primary productivity based on chlorophyll fluorescence parameter Fo. J Plant Physiol 211: 128-135. DOI: 10.1016/j.jplph.2016.12.015.

Chisti Y. 2007. Biodiesel from microalgae. Biotechnol Adv 25: 294-306. DOI: 10.1016/j.biotechadv.2007.02.00.

de Jonge V. 1980. Fluctuations in the organic carbon to chlorophyll-a ratios for estuarine benthic diatom populations. Mar Ecol Prog Ser 2: 345-353. DOI:10.3354/meps002345.

Dewata AP. 2013. Analysis of the potential for greenhouse gases $\left(\mathrm{CH}_{4}\right.$ and $\mathrm{CO}_{2}$ ) in intensive shrimp farming and community perceptions in its management, Tulang Bawang District, Lampung Province. [Thesis]. Bogor Agricultural University, Bogor. [Indonesian]

Gardner ES, Diaz-Saiz J. 2008. Exponential smoothing in the telecommunications data. Int $\mathrm{J}$ Forecast 24: 170-174. DOI: 10.1016/j.ijforecast.2007.05.00.

Geider RJ, Osborne BA. 1992. Algal Photosynthesis. Springer Science+Business Media, Dordrecht.

Gieskes W, Kraay G. 1989. Estimating the carbon-specific growth rate of the major algal species groups in eastern Indonesian waters by $14 \mathrm{C}$ labeling of taxon-specific carotenoids. Deep-Sea Res 36: 1127-1139. DOI: 10.1016/0198-0149(89)90096-4.

Hill R, Bellgrove A, Macreadie PI, Petrou K, Beardall J, Steven A, Ralph PJ. 2015. Can macroalgae contribute to blue carbon? An Australian perspective. Limnol Oceanogr 60: 1689-1706. DOI 10.1002/lno.10128.

Hilmi E, Parengrengi Vikaliana R, Kusmana C, Iskandar Sari LK, Setijanto. 2017. The carbon conservation of mangrove ecosystem applied REDD program. Reg Stud Mar Sci 16: 152-161. DOI: 10.1016/j.rsma.2017.08.005.
Ilman M, Dargusch P, Dart P, Onrizal. 2016. A historical analysis of the drivers of loss and degradation of Indonesia's mangroves. Landuse Pol 54: 448-459. DOI: 10.1016/j.landusepol.2016.03.01.

Iriarte A, Purdie A. 1994. Size distribution of chlorophyll-a biomass and primary production in a temperate estuary (Southampton Water): The contribution of photosynthetic picoplankton. Mar Ecol Prog Ser 115: 283-297. DOI: 10.3354/meps115283

Jeong ML, Gillis JM, Hwang JY. 2003. Carbon dioxide mitigation by microalgal photosynthesis. Bull Korean Chem Soc 24: 1763-1766. DOI: $10.5012 /$ bkcs.2003.24.12.1763.

Kaswadji RF, Widjaja F, Wardiatno Y. 1993. Produktifitas primer dan laju pertumbuhan fitoplankton di perairan Pantai Bekasi (Phytoplankton Primary Productivity and Growth Rate in the Coastal Waters of Bekasi Regency). Jurnal Ilmu-ilmu Perairan dan Perikanan Indonesia 1 (2): 1-15. [Indonesian]

Kauffman JB, Bernardino AF, Ferreira TO, Bolton NW, Gomes LE de O, Nobrega GN. 2018. Shrimp ponds lead to massive loss of soil carbon and greenhouse gas emissions in northeastern Brazilian mangroves. Ecol Evol 8: 5530-5540. DOI: 10.1002/ece3.4079.

Kauffman JB, Heider C, Norfolk J, Payton F. 2014. Carbon stocks of intact mangroves and carbon emissions arising from their conversion in the Dominican Republic. Ecol Appl 24 (3): 518-527. DOI: 10.1890/13-0640.1.

Kirk JTO. 2011. Light and Photosynthesis in Aquatic Ecosystems. Cambridge University Press, New York.

Krismono, Astuti LP, Sugianto Y. 2017. Karakteristik kualitas air Danau Limboto Provinsi Gorontalo (Water quality characteristics of Limboto Lake, Gorontalo Province). Jurnal Penelitian Perikanan Indonesia 15 (1): 59-68. [Indonesian]

Lee Z, Marra J, Perry MJ, Kahru M. 2014. Estimating oceanic primary productivity from ocean color remote sensing: A strategic assessment. J Mar Syst 149: 50-59. DOI: 10.1016/j.jmarsys.2014.11.01.

Liu H, Ren H, Hui D, Wang W, Liao B, Cao Q. 2014. Carbon stocks and potential carbon storage in the mangrove forests of China. J Environ Manage 133: 86-93. DOI: 10.1016/j.jenvman.2013.11.037

Ma S, Tao Z, Yang X, Yu Y, Zhou X, Ma W, Li Z. 2014. Estimation of marine primary productivity from satellite-derived phytoplankton absorption data. IEEE J Sel Top Appl Earth Obs Remote Sens 7: 3084-3092. DOI: 10.1109/JSTARS.2014.2298863.

Mardhiya IR, Surtono A, Suciyati SW. 2017. Sistem akuisisi data pengukuran kadar oksigen terlarut pada air tambak udang menggunakan sensor dissolved oxygen (Data acquisition system for measuring dissolved oxygen levels in shrimp pond water using a dissolved oxygen sensor). Jurnal Teori dan Aplikasi Fisika 6: 133140. DOI:10.23960/JTAF. V6I1.1836. [Indonesian]

Mercado-santana JA, Santamaría E, González-silvera A, Gracia-escobar MF, Millán-núñez R, Torres-navarrete C, Santamaría-del-ángel E, González-silvera A, Sánchez-velasco L, Gracia-escobar MF. 2017. Productivity in the gulf of California large marine ecosystem. Environ Dev 22: 18-29. DOI: 10.1016/j.envdev.2017.01.003.

Mitra A, Zaman S. 2015. Blue Carbon Reservoir of the Blue Planet. Springer, New Delhi.

Moreira D, Pires JCM. 2016. Atmospheric CO2 capture by algae: Negative carbon dioxide emission path. Bioresour Technol 215: 371379. DOI: 10.1016/j.biortech.2016.03.060

Nontji A. 1984. Biomass and phytoplankton productivity in the waters Jakarta Bay and its relation to environmental factors. [Dissertation]. Bogor Agricultural University, Bogor. [Indonesian].

Parsons TR, Takahashi M, Hargrave B. 1992. Biological Oceanographic Processes. Elsevier Science, New York.

Raharja A, Angraeni W, Vinarti RA. 2010. Implementing method of exponential smoothing for phone duration usage forcasting in PT. Telkomsel DIVRE3 Surabaya. SISFO-Jurnal Sistem Informasi 1-9. DOI: $10.21149 / 7729$. [Indonesian]

Rahman, Effendi H, Rusmana I. 2017. Stock estimation and carbon absorption of mangrove in Tallo River, Makassar. Jurnal Ilmu Kehutanan 2: 19-28. DOI: 10.1111/gcb.13051. [Indonesian]

Reeder BC. 2017. Primary productivity limitations in relatively low alkalinity, high phosphorus, oligotrophic Kentucky reservoirs. Ecol Eng 108: 477-481. DOI: 10.1016/j.ecoleng.2017.06.009.

Rifqi M, Widigdo B, Wardiatno Y, Mashar A, Adianto W. 2020. The daily variance of $\mathrm{CO} 2$ and $\mathrm{CH} 4$ emission from shrimp ponds. IOP Conf Ser: Earth Environ Sci 420: 012026. DOI: 10.1088/17551315/420/1/012026

Risteski D, Kulakov A, Davcev D. 2004. Single exponential smoothing method and neural network in one method for time series prediction. 
In: Conference on Cybernetics and Intelligent Systems: IEEE Singapore, 1-3 December. DOI: 10.1109/iccis.2004.1460680.

Sayre R. 2010. Microalgae: The potential for carbon capture. Biosci 60 (9): 722-727. DOI:10.1525/bio.2010.60.9.9.

Sidik F, Lovelock CE. 2013. $\mathrm{CO}_{2}$ Efflux from shrimp ponds in Indonesia. PLoS One 8 (6): e0066329. DOI: 10.1371/journal.pone.0066329.

Siikamäki J, Sanchirico JN, Jardine S, McLaughlin D, Morris D. 2013. Blue carbon: Coastal ecosystems, their carbon storage, and potential for reducing emissions. Environ Dev Sustain 55 (6): 14-29. DOI: 10.1080/00139157.2013.8439.

Silva TSF, Costa MPF, Melack JM. 2009. Annual net primary production of macrophytes in the eastern amazon floodplain. Wetlands 29 (2): 747-758. DOI: $10.1672 / 08-107.1$.

Singh UB, Ahluwalia AS. 2013. Microalgae a promising tool for carbon sequestration. Mitig Adapt Strat G 18 (1): 73-95. DOI: 10.1007/s11027-012-9393-3

Steigenberger S, Terjung F, Grossart H, Reuter R. 2004. Bluefluorescence of NADPH as an indicator. In: EARSel eProceedings. European Association of Remote Sensing Laboratories, Strasbourg, France.
Umaly RC, Cuvin LA. 1988. Limnology: Laboratory and Field Guide Physico-Chemical Factors, Biology Factors. National Book Store Publ., Manila.

Vallina SM, Cermeno P, Dutkiewicz S, Loreau M, Montoya JM. 2017. Phytoplankton functional diversity increases ecosystem productivity and stability. Ecol Modell 361: 184-196. DOI: 10.1016/j.ecolmodel.2017.06.020.

Wetzel RG. 2001. Limnology: Lake and River Ecosystems, 3rd Ed. Academic Press, San Diego, CA.

Xiao X, Wang Y, Zhang H, Yu X. 2015. Effects of primary productivity and ecosystem size on food-chain length in Raohe River, China. Acta Ecologica Sinica 35: 29-34. DOI: 10.1016/j.chnaes.2015.04.003

Yang D, Chen W, Chen Y, Zhang Y, Ji J. 2002. Optical measurements of primary production in Meiliang Bay, Taihu Lake. J Lake Sci 14: 363368.

Yang P, Lai DYF, Huang JF, Tong C. 2017. Effect of drainage on $\mathrm{CO}_{2}$, $\mathrm{CH}_{4}$, and $\mathrm{N}_{2} \mathrm{O}$ fluxes from aquaculture ponds during winter in a subtropical estuary of China. J Environ Sci 65: 72-82. DOI: 10.1016/j.jes.2017.03.024 